\title{
Spatial distribution and mapping of crenate broomrape infestations in continuous broad bean cropping
}

José Luis González-Andújar

Corresponding author. Institute for Sustainable Agriculture, C.S.I.C., Apdo.4084, 14080-Córdoba, Spain; andujar@cica.es

Antonio Martínez-Cob

Experimental Station of Aula Dei, C.S.I.C., Apartado 202, 50080-Zaragoza, Spain

Francisca López-Granados

Institute for Sustainable Agriculture, C.S.I.C., Apdo.4084, 14080-Córdoba, Spain

Luis García-Torres

Institute for Sustainable Agriculture, C.S.I.C., Apdo.4084, 14080-Córdoba, Spain

\begin{abstract}
Geostatistical techniques were used to describe and map the spatial distribution of crenate broomrape populations parasitizing broad bean over 6 yr (from 1985 to 1990). In the first year, the spatial distribution was random, but from 1986 to 1989 , crenate broomrape populations were clearly aggregated. The crenate broomrape infection severity (IS: number of emerged broomrape $\mathrm{m}^{-2}$ ) increased every year, from an average of 0.45 in 1985 to 29.4 in 1989 , with a slight decrease the following year (IS $=27.4)$. Spherical functions provided the best fit because the cross-validation criteria were accomplished in all study cases. Kriged estimates were used to draw contour maps of the populations. About $34.3,43.3$, and $74.3 \%$ of the field plot surface exhibited an IS $\geq 1$ (economic threshold) in 1985, 1986, and 1987, respectively, and nearly $100 \%$ of the area exceeded the economic threshold from 1988 to 1990; 1985 and 1986 were key years for control of the parasitic weed population. The percentage of infested area at different IS intervals in each year's map obtained by kriging was used to estimate the percentage of yield losses in each infested area $\left(Y_{A}\right)$ with the equation: $Y_{A}=A * Y_{\max }^{*}(1-I S * 0.124)$, where $A$ is the infested area at a given IS interval and $Y_{\max }$ is the expected broomrape-free broad bean yield. Yield losses under different IS intervals were compared with yield loss attributable to a uniform distribution of crenate broomrape. Results showed that yield loss assuming a uniform distribution of crenate broomrape was clearly overestimated, which is important to avoid overuse of herbicides.
\end{abstract}

Nomenclature: Crenate broomrape, Orobanche crenata Forsk. ORACR; Vicia faba L.

Key words: Geostatistics, kriging, parasitic weed, patch, precision farming.
Crenate broomrape is an obligate root parasite that causes considerable yield losses in many field crops, particularly legumes such as broad bean, peas (Pisum sativum L.), and lentils (Lens esculenta Medik.). It mainly occurs in the Mediterranean region, the Middle East, and Eastern Europe (Parker 1994).

A competition model of crenate broomrape in broad bean developed by Mesa-García and García-Torres (1984) showed that an average of four emerged crenate broomrape per crop plant reduced broad bean yield by one-half. López-Granados and García-Torres (1993a, 1993b) modeled the demography and population dynamics of crenate broomrape in continuous broad bean cropping. They found that crenate broomrape population size followed a sigmoidal model in which population growth stabilized at a value of 26 emerged broomrape per square meter. A long-term study to model the longevity of crenate broomrape seed under field conditions was carried our by López-Granados and García-Torres (1999). They fitted seed longevity with a negative exponential model and used it to simulare new infestations and to study factors influencing persistence of broomrape infestations. Further, a populacion dynamic model of a crenate broomrape broad bean system was developed to evaluate cropping frequency (consecurive and every-third year broad bean cropping) and planing date (early, intermediate, and late) with and without parasite control (López-Granados and García-Torres 1997). A sensitivity analysis was performed to derermine the robustness of the model; the model was then used to evaluare performance of a variety of broomrape-control strategies. Based on that model, LópezGranados and García-Torres (1998) developed a bioeconomic model to investigate the short- and long-term economic implications of controlling crenate broomrape in broad beans under different management strategies, including a nonherbicidal strategy, applying herbicide once a year if densities exceeded a threshold, and applying herbicide every year. From this research the economic threshold was determined to be around one emerged broomrape per square meter.

\section{Weed Spatial Distribution Studies}

Field observations clearly show the spatial aggregation of weeds. The tacit assumption of a random distribution of weeds is the foundation of most weed-crop competition and population dynamic studies, and that assumption has misled population evolution models and the estimation of crop yield because yield loss often was overestimated (Auld and Tisdell 1988; Cousens 1985; González-Andújar and Fernández-Quintanilla 1991; Lindquist et al., 1998).

Previous attempts to describe numerical distribution of weeds have used dispersion indices (variance-to-media ratio, Morisita's index, etc.) and statistical distribution (negative binomial distribution, Taylor power law, etc.) (Clark et al. 1996; Dessaint et al. 1991; Marshall 1988; Wiles et al. 1992). However, these methods fail to account for the location, separation, and two-dimensional distribution of weeds, and they cannot be used to estimate density, location, 
TABLE 1. Observed infection severity (IS) (emerged broomrape $\mathrm{m}^{-2}$ ), estimated by kriging at 1.0 by $1.0 \mathrm{~m}$ grid cells.

\begin{tabular}{lccccccc}
\hline Year & Average & Median & $\begin{array}{c}\text { Standardized } \\
\text { skewness }\end{array}$ & Average $^{\mathbf{a}}$ & Median $^{2}$ & IS $\geq 1(\%)^{\mathbf{a}}$ & IS $\geq 1(\%)$ \\
\hline 1985 & 0.45 & 0 & 1.8 & 0.45 & 0.46 & 1.8 & 34.3 \\
1986 & 0.89 & 0.8 & 1.7 & 0.88 & 0.71 & 32.5 & 43.3 \\
1987 & 4.6 & 3 & 1.9 & 4.5 & 3.4 & 88.0 & 74.3 \\
1988 & 18.8 & 18 & 0.5 & 19.2 & 19.8 & 99.5 & 96.7 \\
1989 & 29.4 & 32 & 0.4 & 38.2 & 38.9 & 100.0 & 99.2 \\
1990 & 27.3 & 26 & 1.1 & 27.4 & 27.0 & 98.2 & 89.3 \\
\hline
\end{tabular}

astimated values.

or arrangement of weeds in agricultural fields (Mortensen et al. 1993). Therefore, alternative methods that rely on the geographic location of samples must be used to study their spatial arrangement. Geostatistical techniques offer such an alternative.

Geostatistics is a branch of applied statistic that concentrates on the description of spatial patterns and that estimates values at unsampled locations. Geostatistical analysis has been used to map spatial distribution of weeds in fields (Cardina et al. 1995; Donald 1994; Heisel et al. 1996, 1999). Mapping emerged weeds provides the most accurate description of weed spatial variability in the field and ensures that estimation is unbiased and has minimum variance (Cressie 1991; Kristensen and Ersbøll 1995). Use of such maps makes it possible to regulate weed management as a function of local weed density (Heisel et al. 1996).

In the previous crenate broomrape studies, spatial distribution was not taken into account, and, therefore, distribution in the broad bean crop was assumed to be random. Thus, this paper intends to (1) describe crenate broomrape spatial distribution over time, (2) use this knowledge to estimate yield loss, and (3) compare yield losses, assuming both a patchy and uniform distribution of crenate broomrape.

\section{Materials and Methods}

\section{Study Area and Sampling}

Field studies of crenate broomrape in broad bean were conducted at Tomejil (Seville, Spain) for 6 consecutive years (1985 to 1990); a more detailed description of the study area is given by López-Granados and García-Torres (1993a, 1993b). The experimental site was a $20 \mathrm{~m}$ (x-coordinate) by $40 \mathrm{~m}$ (y-coordinate) section of a field with a natural infestation of 0.13 emerged broomrape $\mathrm{m}^{-2}$ in 1984 . The soil was a vertisol, with $68 \%$ clay, $1.3 \%$ organic matter, and a $\mathrm{pH}$ of 8.4 .

Before sowing, the study site was plowed, disked, and harrowed. The broad bean crop was sown in mid-December of each year. The distance between rows was $70 \mathrm{~cm}$, and the distance between plants within a row was $20 \mathrm{~cm}$. If necessary, between 6 and 10 wk after crop emergence, one to two shallow harrow cultivations were performed between the rows for general weed control. No supplemental control of crenate broomrape was conducted. In June of each year of the study (1985-1990) and again before broad bean harvest, the number of emerged crenate broomrape plants was counted for every broad bean plant in one of every four rows, using a grid of $2.8 \mathrm{~m}$ by $1 \mathrm{~m}$, for a total of 220 counts each year. Infection severity (IS) data was expressed as emerged broomrape plants per square meter.

\section{Geostatistical Analysis}

The spatial variation of crenate broomrape IS was described and quantified (Isaaks and Srivastava 1989; Webster and Oliver 1990). The variogram, a central tool of geostatistics, describes the structure and spatial scale of variation by measuring the degree of spatial correlation between sampling points. Geostatistical prediction, or kriging, enables a property to be predicted optimally at an unsampled location. Prediction of the property can be made for either points (punctual kriging) or over areas (block kriging), and estimates are unbiased and have minimum variance.

Data for each year were treated as a study case and were statistically and geostatistically analyzed. Data were normally distributed, so statistical transformations were not needed. Semivariogram models were fit to experimental semivariogram values to assess the spatial structure of variation in emerged broomrape per square meter. Isotropy was assumed because experimental semivariograms were fitted in four directions over the field and directional differences were not observed. Thus, omnidirectional experimental semivariograms were computed for an interval distance of $1 \mathrm{~m}$ as follows (Isaaks and Srivastava 1989; Journel and Huijbregts 1978):

$$
\gamma^{*}(h)=\frac{1}{2 N(h)} \sum_{i=1}^{N(h)}\left[z\left(x_{i}+h\right)-z\left(x_{i}\right)\right]^{2}
$$

where: $\gamma^{*}(h)=$ experimental semivariogram value at distance interval $h, N(h)=$ number of sample value pairs within the distance interval $h$, and $z\left(x_{i}\right), z\left(x_{i}+h\right)=$ sample values at two sample points separated by a distance interval $h . N(h)$ varied from 289 (247 for year 1989) sample value pairs, at distance interval $1-2 \mathrm{~m}$, to 2,743 (2,306 for year 1989) at distance interval 8-9 $\mathrm{m}$.

Several semivariogram functions were evaluated to identify the model that produced the best fit. The best-fit models were used to perform ordinary point kriging on a regular grid of $1 \mathrm{~m}$ by $1 \mathrm{~m}$.

A cross-validation procedure was performed to check model validity. The estimated model parameters were modified in a "trial-and-error" procedure until adequate crossvalidation statistics were obtained (Isaaks and Srivastava 1989). To cross-validate a semivariogram model, each sample value was deleted one by one from the data set, and kriging, described below, was used to estimate crenate broomrape IS at the location of the deleted sample using the remaining samples. Differences between estimated and 
TABLE 2. Spherical semivariogram functions of the crenate broomrape infection severity (IS; emerged broomrape $\mathrm{m}^{-2}$ ).

\begin{tabular}{lcccccc}
\hline Year & $\begin{array}{c}\text { Nugget } \\
\text { variance } \\
(\%)\end{array}$ & $\begin{array}{c}\sum\left(\mathrm{C}_{\mathrm{o}}+\mathrm{C}\right)^{\mathbf{2}} \\
(\text { sill) }\end{array}$ & $\begin{array}{c}\text { Partial } \\
\text { sill }\end{array}$ & $\begin{array}{c}\text { Range } \\
(\mathrm{m})\end{array}$ & Sill $^{\mathrm{b}}$ & Range $^{\mathrm{b}}$ \\
\hline 1985 & $0.4(85)^{\mathrm{c}}$ & 0.47 & 0.07 & 5.1 & - & - \\
1986 & $1.25(57)$ & 2.2 & 0.95 & 5.2 & - & - \\
1987 & $14(39)$ & 36 & 22 & 8.5 & - & - \\
1988 & $50(25)$ & 200 & 150 & 10.0 & - & - \\
1989 & $185(32)$ & 585 & 400 & 8.7 & - & 18 \\
1990 & $375(53)$ & 705 & 160 & 4.1 & 170 & - \\
\hline
\end{tabular}

a Asymptotic plateau value (nugget effect plus sill) of the semivariogram function attained at the range distance.

b Second nested structure.

c Values in parenthesis are nugget variance expressed as a percent of the sum $C_{0}+C$.

experimental values of IS were summarized using the following cross-validation statistics: mean estimation error $(M E E)$, mean squared error (MSE), and standardized mean square error (SMSE) (Hevesi et al. 1992; Isaaks and Srivastava 1989). A model was considered to ensure unbiased estimates of IS if the $M E E$ was not significantly different than zero and was considered accurate if the $M S E$ was, as a practical rule, less than the variance of sample values (Hevesi et al. 1992). The SMSE indicated the consistency of the observed MSE with the calculated estimation uncertainty, expressed as the kriging estimation error variance, described below (Isaaks and Srivastava 1989; Journel and Huijbregts 1978). Model validity was satisfied if the SMSE was within the interval $1 \pm 2(2 / m)^{1 / 2}$ (Hevesi et al. 1992).

Once cross-validated, the model semivariograms were used to estimate crenate broomrape infection severity at points located on a regular grid of $1 \mathrm{~m}$ by $1 \mathrm{~m}$ cells by applying ordinary point kriging. This geoestatistical technique provides the best linear estimator (minimum variance) of a particular variable at a point where it is unknown (Journel and Huijbregts 1978). Sample values used for kriging at each interpolation point were limited to a search radius of $5 \mathrm{~m}$ and a maximum of 32 sample values.

The geostatistical analysis was performed with the geostatistical package COKRIG6 (Hevesi, personal communication, 1992). As a final step, SURFER for WINDOWS (version 6.01) was used to map the kriged estimates of crenate broomrape infection severity.

\section{Spatial Distribution of Yield Losses}

Kriged maps of crenate broomrape infection severity were used to determine percent infested area based on three IS intervals (IS $=0,0-1, \geq 1$ emerged broomrape $\mathrm{m}^{-2}$, the economic threshold of broomrape is IS $=1$ plants $\mathrm{m}^{-2}$. The percent yield loss $\left(\% \mathrm{Y}_{1}\right)$ attributable to each crenate broomrape infection severity interval was determined using the following model (Mesa-García and García-Torres 1984):

$$
\% \mathrm{Y}_{1}=100 * \text { IS * } 0.124
$$

In order to estimate the yield for every infested area $\left(\mathrm{Y}_{\mathrm{A}}\right)$ affected by each IS level, the following equation was used:

$$
\mathrm{Y}_{\mathrm{A}}=\mathrm{A} * \mathrm{Y}_{\max } *(1-\mathrm{IS} * 0.124)
$$

In this equation, $A$ is the area under every IS interval; $Y_{\max }$ is the expected broomrape-free broad bean yield (estimated as $2.800 \mathrm{~kg} \mathrm{ha}^{-1}$, López-Granados and García-Torres 1998). Yield of the $20 \mathrm{~m}$ by $40 \mathrm{~m}$ study site for each year was determined by summing $Y_{A}$ for every IS level.

Spatially explicit and nonspatial estimates of yield loss were compared. Assumptions about a uniform distribution of crenate broomrape were based on the results of a demographic broomrape model developed by López-Granados and García-Torres (1993a), and percent yield loss was estimated using Equation 2.

\section{Results and Discussion}

\section{Overall IS Evolution}

The summary statistics for observed Crenate broomrape infection severity (IS: number of emerged broomrape $\mathrm{m}^{-2}$ ) are presented in Table 1 . IS increased every year from 0.45 in 1985 to 29.4 in 1989 , with a slight decrease the following year (IS $=27.3$ ). The fall of the IS in the last year was probably attributable to a large broomrape seedbank giving rise to high seedling densities, resulting in density-dependent mortality (López-Granados and García-Torres 1993a).

\section{Spatial Distribution}

The semivariogram model parameters for each year are listed in Table 2. Spherical functions provided the best fit because the cross-validation criteria were met in all study cases (Table 3).

The semivariogram nugget coefficient allows an interpretation of the required scale for defining the spatial variability or of the existing uncertainty in experimental values. Nugget values increased in each year of the study, from 0.4 in 1985 to 375 in 1989 (Table 2), expressing the need for diverse scales of assessing spatial variability smaller than that obtained with the sampling.

The nugget effect was $85 \%$ of the total sum of the nugget plus sill in 1985. This indicates a very weak spatial dependence of the distribution of crenate broomrape, and, consequently, it indicates that the distribution was largely random. In subsequent years the nugget effect ranged from $25 \%$ (1988) to $57 \%$ (1986) of the total sum of nugget plus 
a

1985

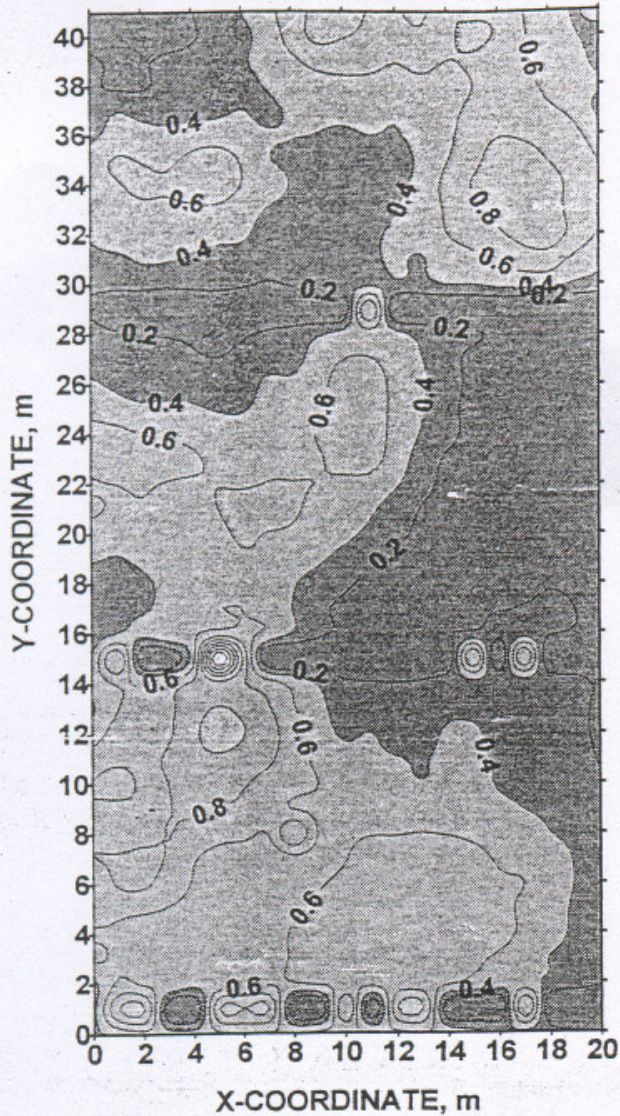

b

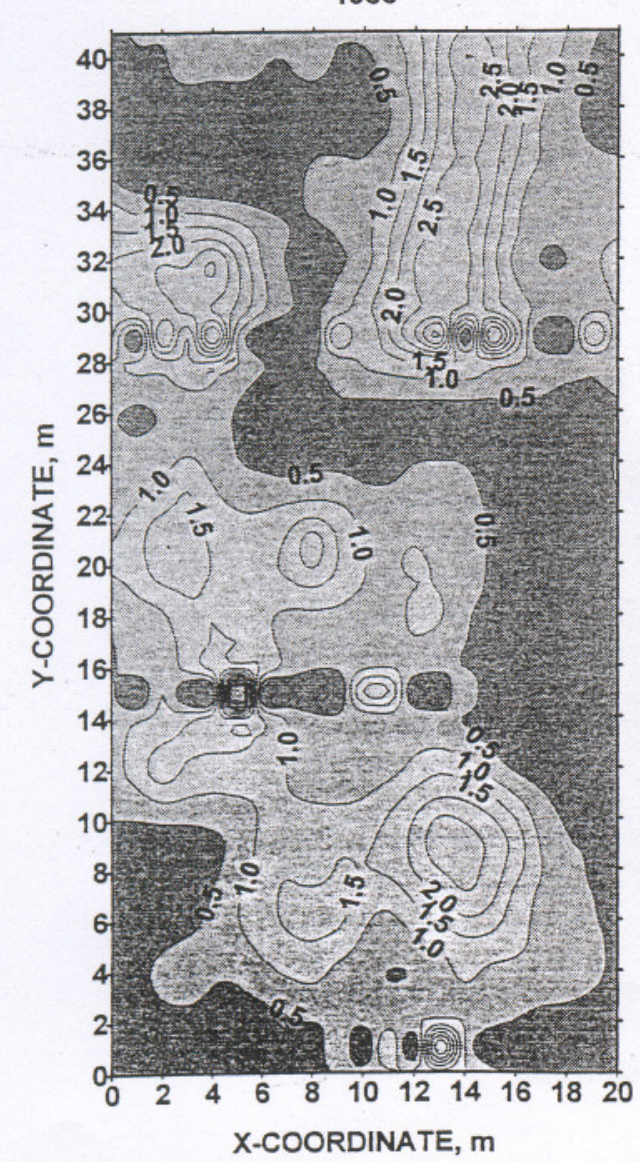

C

1987

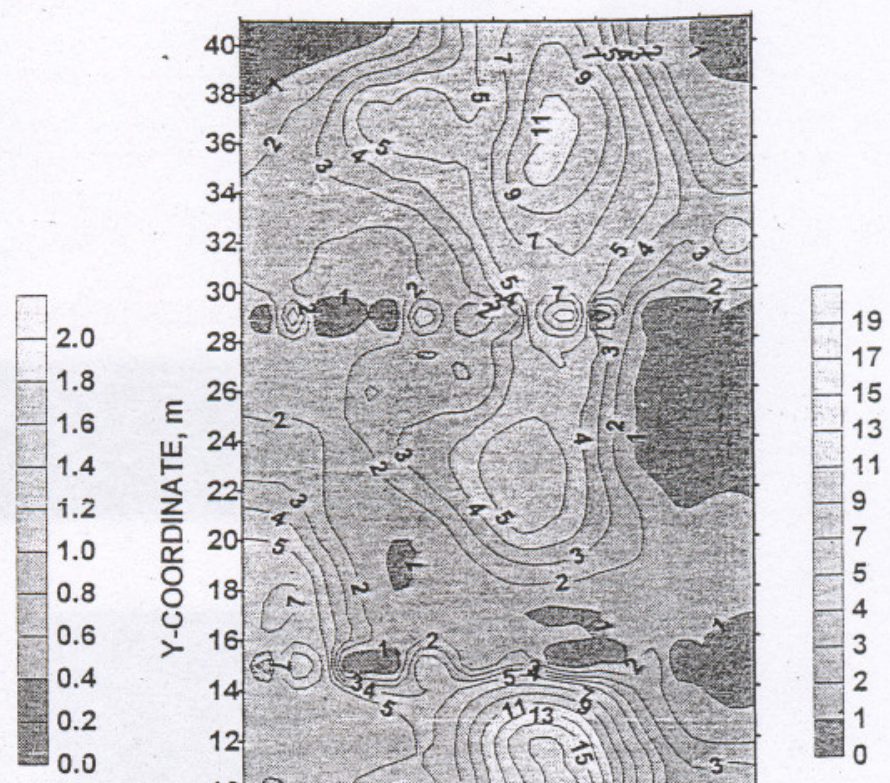

-8
-7
-6
-5
4
3
2
2
1
0

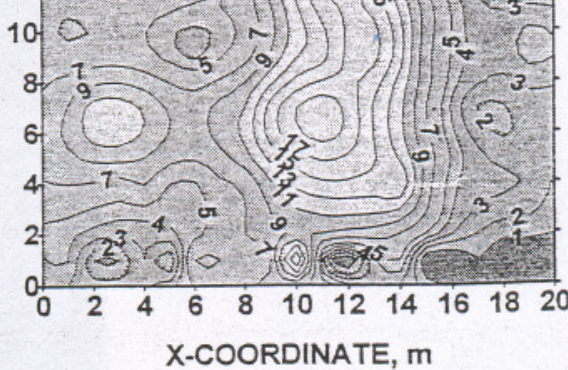

d

1988

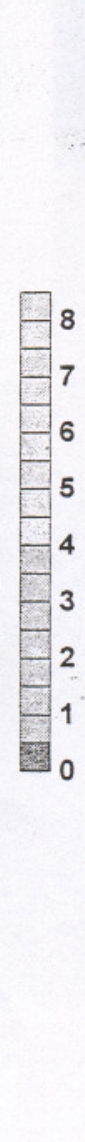




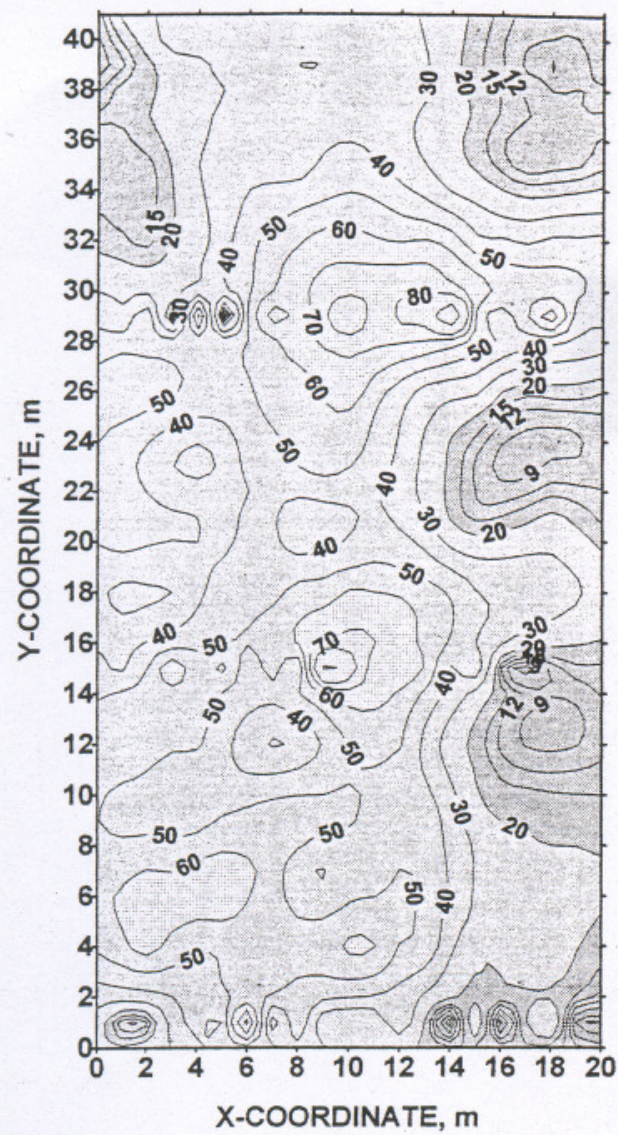

f

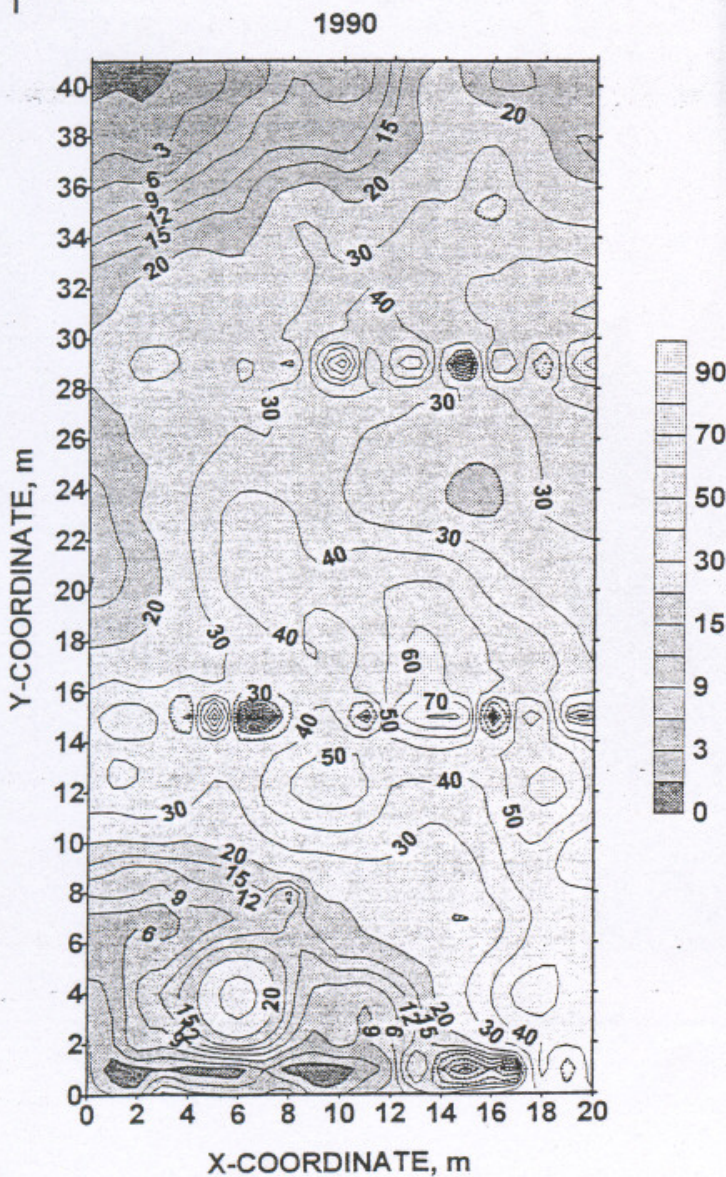

TABLE 3. Semivariogram cross-validation statistics.

\begin{tabular}{lrrrr}
\hline Year & MEE $^{\mathrm{a}}$ & MSE $^{\mathrm{b}}$ & SMSE $^{\mathrm{c}}$ & $1 \pm 2(2 / \mathrm{m})^{0.5}$ \\
\hline 1985 & $1.8^{\mathrm{ns}}$ & 96.7 & 1.004 & $1 \pm 0.163$ \\
1986 & $1.3^{\mathrm{ns}}$ & 92.4 & 1.012 & $1 \pm 0.163$ \\
1987 & $0.4^{\mathrm{ns}}$ & 59.2 & 0.976 & $1 \pm 0.163$ \\
1988 & $-0.2^{\mathrm{ns}}$ & 50.6 & 1.028 & $1 \pm 0.163$ \\
1989 & $0.2^{\mathrm{ns}}$ & 52.1 & 0.974 & $1 \pm 0.176$ \\
1990 & $1.1^{\mathrm{ns}}$ & 76.5 & 1.048 & $1 \pm 0.163$ \\
\hline
\end{tabular}

${ }^{a}$ Mean estimation error expressed as percentage of the sample mean; ns $=$ not significantly different from $0(\alpha=0.05)$.

b Mean squared error expressed as percentage of the sample variance.

c Standardized mean square error.

sill, indicating moderate to relatively strong spatial dependence for the distribution of crenate broomrape populations.

Similarly, the sill increased every year from 0.07 in 1985 to 705 in 1990 , a result of the increase of crenate broomrape infection severity. The low sill value of the first year is the result of a small mean density and a random distribution. In successive years, the population growth resulted in a range of values varying from 8.5 to $10 \mathrm{~m}$ (Table 2).

\section{Mapping}

Generally the kriging and other nonspatial estimates of IS were very similar to the average sample values (Table 1 ). An exception to this trend was observed when $\%$ IS $\geq 1$ (the economic threshold) in 1985 and 1986 years when crenate broomrape exhibited weak to moderate spatial variability. For example, in 1985 only $1.8 \%$ of the kriged estimates had an IS $\geq 1$ compared to $34.3 \%$ for the actual values (Table 1).

The isoline maps of IS drawn from the kriged estimates are shown in Figure 1. About 34.3, 43.3, and $74.3 \%$ of the study site had an IS $\geq 1$ in 1985,1986 , and 1987 , respectively (Figures $1 a-c$ ). Furthermore, nearly $100 \%$ of the area exceeded the economic threshold of $\geq 1$ emerged broomrape per square meter in 1988 to 1990 (Figures 1d-f). Therefore, 1985 and 1986 were the key years to control the parasitic weed population. Moreover, if a selective herbicide was applied in 1985 and 1986 to areas exceeding the economic threshold, a reduction of 66 and $57 \%$ in herbicide use would have been possible. These results are important, as they demonstrate the potential value of site-specific management for this weed. Such an approach to management of crenate broomrape will be crucial if there are environmental penalties against for excessive use of herbicides, such as are now required by many large food wholesalers, in response to consumer demand.

Crenate broomrape distribution between 1986 and 1987 is consistent with the discussion reported by López-Granados and García-Torres (1998), in which they concluded that sowing faba bean (Vicia faba L.) every year, and no herbicide application is a suitable strategy only when IS $<1$.

\section{Spatial Yield Loss Estimation}

Expected crenate broomrape-free broad bean yield in the whole area (0.08 ha) was $224 \mathrm{~kg}$ (Table 4). Percent yield

FIGURE 1. Continued. 
TABLE 4. Percentage of yield losses (\% $\left.\mathrm{Y}_{1}\right)$ according to an uniform distribution of crenate broomrape expressed as an average of infection severity (IS, or number of emerged broomrape $\mathrm{m}^{-2}$ ) and a patchiness distribution (different intervals of IS).

\begin{tabular}{|c|c|c|c|c|c|c|c|c|c|}
\hline \multirow[b]{2}{*}{ Year } & \multicolumn{4}{|c|}{ Uniform } & \multicolumn{5}{|c|}{ Sparial } \\
\hline & $\begin{array}{c}\text { IS } \\
\text { (emerged } \\
\text { broomrape } \\
\mathrm{m}^{-2} \text { ) }\end{array}$ & $\%\left[A^{2}\right.$ & $\mathrm{Y}_{\mathrm{t}}^{\mathrm{b}}$ & $\% \mathrm{Y}_{1}$ & $\begin{array}{c}\text { IS } \\
\text { (emerged } \\
\text { broomrape } \\
\mathrm{m}^{-2} \text { ) }\end{array}$ & $\%$ IA & $\mathrm{Y}_{2}^{\mathrm{c}}$ & $Y_{t}$ & $\% Y_{t}$ \\
\hline 1985 & 0.49 & 100 & $\underset{208}{\mathrm{~kg} \mathrm{ha}^{-1}}$ & 7 & $\begin{aligned} & 0 \\
& 0-1 \\
\geq & 1\end{aligned}$ & $\begin{array}{l}66 \\
29 \\
5.3\end{array}$ & $\begin{array}{r}145 \\
56 \\
7\end{array}$ & 210 & 6 \\
\hline 1986 & 0.89 & 100 & 199 & 11 & $\begin{aligned} & 0 \\
& 0-1 \\
\geq & 1\end{aligned}$ & $\begin{array}{l}57 \\
21 \\
22.3\end{array}$ & $\begin{array}{r}128 \\
41 \\
33\end{array}$ & & \\
\hline 1987 & 4.6 & 100 & 96.2 & 43 & $\begin{aligned} & 0 \\
& 0-1 \\
\geq & 1\end{aligned}$ & $\begin{array}{l}26 \\
16 \\
59\end{array}$ & $\begin{array}{l}56 \\
32 \\
73\end{array}$ & 161 & 10 \\
\hline
\end{tabular}

a \%I: \% of infested area according to every IS interval.

${ }^{b} Y_{t}$ : Broad bean total yield of the whole area $=\Sigma Y_{A}$.

${ }^{c} \mathrm{Y}_{\mathrm{A}}$ : Broad bean yield according to every broomrape-infested area.

loss $\left(\% \mathrm{Y}_{1}\right)$, taking into account the $\%$ of infested area and the different intervals of IS, was $6 \%, 10 \%$, and $28 \%$, for 1985,1986 , and 1987, respectively (Table 4). Percent yield loss under a uniform broomrape distribution was $7 \%, 11 \%$, and $43 \%$ for 1985,1986 , and 1987 , respectively (Table 4). These values indicate an overestimation of yield loss by $16.6 \%$ in $1985,12 \%$ in 1986 , and $53.5 \%$ in 1987 . Furthermore, an increase of patchiness from 1985 to 1987 ( Table 2) increases the likelihood that \% yield loss will be overestimated (Table 4). Our results emphasize the potential for errors when estimating yield loss through the adoption of a single mean density estimate when there is spatial structure in the weed community (Auld and Tisdell 1988; GonzálezAndújar et al. 1999).

Consequently, knowledge of the spatial variability of crenate broomrape infestation was necessary to estimate yield loss accurately and to increase crenate broomrape management efficiency by selectively applying herbicide only to areas exceeding the economic threshold. Knowledge of spatial variability allows one to prevent overuse of herbicides and to decrease the likelihood of development of resistant biotypes.

Study of spatial variability is important to explore the distribution of crenate broomrape infestations (uniform or patchy) throughout the semivariogram, to assess the value of site-specific herbicide application (precision farming) to patches exceeding the economic threshold (saving herbicide and money), and to avoid overestimating yield losses.

\section{Acknowledgments}

This work has been partially supported by a FEDER project (1FD97-0049) and the Spanish Scientific and Technological Committee (AGF99-0878).

\section{Literature Cited}

Auld, B. A. and C. A. Tisdell. 1988. Influence of spatial distribution of weeds on crop yield loss. Plant Prot. Q. 31:81.
Cardina, J., D. H. Sparrow, and E. McCoy. 1995. Analysis of sparial distribution of common lambsquarters (Chenopdium album) in no-till soybean (Glycine max). Weed Sci. 43:258-268.

Clark, S., J. N. Perry, and E.J.P. Marshall. 1996. Estimating Taylor's power law parameters for weed and the effect of spatial scale. Weed Res. 36: $405-417$.

Cousens, R. 1985. A simple model relating yield loss to weed density. Ann. Appl. Biol. 107:239-252.

Cressie, N. 1991. Statistics for spatial data. New York: Wiley.

Dessaint, F., R. Chadoeuf, and G. Barralis. 1991. Spatial pattern analysis of weed seed in the cultivated soil seed bank. J. Appl. Ecol. 28:721730.

Donald, W. W. 1994. Geostatistics for mapping weeds, with a Canada thistle (Cirsium arvense) patch as a case study. Weed Sci. 42:648-657.

González-Andújar, J. L. and C. Fernandez-Quintanilla. 1991. Modelling the population dynamics of Avena sterilis under dry-land cereal cropping systems. J. Appl. Ecol. 28:16-27.

González-Andújar, J. L., J. N. Perry, and S. R. Moss. 1999. Modeling effects of spatial partern on the seed bank dynamics of Alopecurus myosuroides. Weed Sci. 47:697-705.

Heisel, T., C. Andreasen, and A. K. Ersbøll. 1996. Annual weed distribution can be mapped with kriging. Weed Res. 36:325-337.

Heisel, T., A. K. Ersbøll, and C. Andreasen. 1999. Weed mapping with co-kriging using soil properties. Prec. Agric. 1:39-52.

Hevesi, J. A., J. D. Istok, and A. L. Flint. 1992. Precipitation estimation in mountainous terrain using multivariate geostatistics. Part I: structural analysis. J. Appl. Meteor. 31:661-676.

Isaaks, E. H. and R. M. Srivastava. 1989. An Introduction to Applied Geostatistics. New York: Oxford University.

Journel, A. G. and C. J. Huijbregts. 1978. Mining Geostatistics. London: Academic Press.

Kristensen K. and A. K. Ersbøll. 1995. The use of geostatistic methods in variety trials where some variety is unreplicated. Fifth Working Seminar on Statistical Methods in Variety Testing. Zakopane, Poland, June $12-16,1995$.

Lindquist, J. L., J. A. Dieleman, D. A. Mortensen, G. A. Johnson, and D. Y. Wyse-Pester. 1998. Economic importance of managing spatially heterogeneous weed populations. Weed Technol. 12:7-13.

López-Granados, F. and L. García-Torres. 1993a. Population dynamics of crenate broomrape (Orobanche crenata) in faba bean (Vicia faba). Weed Sci. 41:563-567.

López-Granados, F. and L. García-Torres. 1993b. Seed bank and other demographic parameters of broomrape (Orobanche crenata Forsk.) population in faba bean (Vicia faba L.). Weed Res. 33:319-327.

López-Granados, F. and L. Garcia-Torres. 1997. Modelling the demography of crenate broormape (Orobanche crenata Forsk.) as affected by broad bean planting dates and cropping frequency. Weed Sci. 46:261-268. 
López-Granados, F. and L. García-Torres. 1998. Short and long term implications of controlling broomrape (Orobanche crenata Forsk.) population in faba bean (Vicia faba L.). Crop Prot. 17:139-143.

López-Granados, F. and L. García-Torres. 1999. Longevity of crenate broomrape (Orobanche crenata Forsk.) seed under soil and laboratory. conditions. Weed Sci. 47:161-166.

Marshall, E.J.P. 1988. Field-scale estimates of grass weed populations in arable land. Weed Res. 28:191-198.

Mesa-García, J. and L. García-Torres. 1984. A competition index for Oro_. banche crenata Forsk effects on broad bean (Vicia faba L.). Weed Res. 24:379-382.

Mortensen, D. A., G. A. Johnson, and L. J. Young. 1993. Weed distribution in agricultural fields. Pages 113-124 in P. C. Robert, R. H. Rust and W. E. Larson, eds. Soil Specific Crop Management. American Society of Agronomy, Madison, WI.

Parker, C. 1994. The present state of the Orobanche problem. Pages 1726 in Proceedings of the Third International Workshop on Orobanche and related Striga research.

Webster, R. and M. A. Oliver. 1990. Statistical methods in soil and land resource survey. Oxford: Oxford University Press.

Wiles, L. J., G. W. Oliver, A. C. York, H. J. Gold, and G. G. Wilkerson. 1992. Spatial distribution of broadleaf weeds in North Carolina Soybean (Glycine max) fields. Weed Sci. 40:547-554.

Received December 7, 2000, and approved July 17, 2001. 